\title{
LOCAL BEEF PRODUCTION: WHAT RIO GRANDE DO SUL IS WAITING FOR?
}

Tamara Esteves de Oliveira*

David Santos Freitas**

ABSTRACT: This research aims to verify the municipalities where it might be interesting to invest in a local beef production in the State of Rio Grande do Sul (RS), southern Brazil. The data analyzed combine the cattle units slaughtered and the estimated beef consumption in each municipality. These indicators were used to identify the capacity of each location to meet the local beef demand. This data were associated to the map of RS by the Quantum GIS 1.8 Lisboa software. The most prominent regions were located at the western frontier, at the southeast Campanba, and at the northeast mountain region of the State. The cattle units slaughtered produced at the municipalities of Aceguá, Pedras Altas, Machadinbo, São Valentim, Quatro Irmãos and Sagrada Família is very high, surpassing the municipality's capacity to absorb it. On the other hand, many municipalities have sufficient productions or little surplus to attend the local beef demand, such as Alegrete, in which a local beef production might benefit a higher number of small producers, but other municipalities also seem to have potential for assisting familiar farmers with this strategy such as Dom Pedrito, Bagé, Santa Maria and Pelotas.

KEY WORDS: Alternative food supply chain; Cattle; Product differentiation; Rural development; Short supply chain.

\section{PRODUÇÃO LOCAL DE CARNE BOVINA: O QUE O RIO GRANDE DO SUL ESTÁ ESPERANDO?}

RESUMO: Esta pesquisa tem como objetivo verificar os municípios onde pode ser interessante investir na produção de carne local no Estado do Rio Grande do Sul, ao sul do Brasil. Os dados analisados combinam o número de bovinos abatidos em cada município com o seu consumo de carne bovina estimado. Estes indicadores foram utilizados para identificar a capacidade de cada local para atender sua demanda

\footnotetext{
Pós-doutoranda da Universidade Federal do Rio Grande do Sul (CEPAN/ UFRGS), Porto Alegre, RS, Brasil; E-mail: tamaraesteves@yahoo.com.br

** Doutorando do Programa de Pós Graduação em Biologia pela UNISINOS na área de Manjeo e Conservação de Ecossistemas e da Vida Silvestre, Brasil.
} 
por carne bovina. Os dados foram associados ao mapa do Rio Grande do Sul pelo software Quantum GIS 1.8 Lisboa. As regiões mais importantes localizam-se na fronteira oeste, ao longo da Campanha e na região da serra, nordeste do Estado. A produção de carne em Aceguá, Pedras Altas, Machadinho, São Valentim, Quatro Irmãos e Sagrada Família é muito alta, superando a capacidade destes municípios de consumi-la, e muitos municípios têm produção suficiente ou com pouco excedente para atender a demanda. $\mathrm{O}$ investimento na produção de carne local no município de Alegrete pode beneficiar maior número de pequenos produtores, mas outros municípios também apresentam potencial para auxiliar os agricultores familiares com esta estratégia, como Dom Pedrito, Bagé, Santa Maria e Pelotas.

PALAVRAS-CHAVES: Cadeias alternativas de fornecimentos de alimentos; Cadeia curtas de fornecimento; Desenvolvimento rural; Diferenciação de produtos.

\section{INTRODUCTION}

Food is one of the most important aspects related to poverty, human wellbeing, and sustainable development. Moreover, its production faces the challenge of feeding an emerging population without compromising its ability to survive this process (GODFRAY, 2010). On the other hand, consumers are increasingly concerned about the safety and the socio-environmental risks inherent to the product their purchase, and those expectations are reflected in their desire to trust and establish a relationship to their food, how it is produced and where it comes from (POLLAN, 2006; SEYFANG, 2006).

Nevertheless, the attempts to meet the growing demand for food, especially for animal protein such as beef, has led to an increasing search for efficiency, which benefits the large-scales production systems dedicated to reach as many and as far away markets as possible. These actions contributed to a centralized food production scenario, which, along with the urbanization and of the population, has favored a disconnection between consumers and producers (PEARSON et al., 2011).

Since food is traveling further along the supply chain, there is an emerging social and financial cost related to those large-scale production based on exportations. These concerns have often been translated into concepts such as local foods and/ 
or short supply chains defended as within the precepts of sustainable development and capable of reconnecting local producers and consumers (LYON; COLQUHOUN; JANHONEN-ABRUQUAH, 2003).

Beef supply chain has suffered harder the effects of this discussion, especially in Brazil, as a reflex of the disturbing threat approaching the Amazon Forest and of its expressivity as beef a producer, consumers and exporter. Nevertheless, in Rio Grande do Sul State, southern Brazil, there is a range of native grasslands that may enable the development of a local production, shortening this supply chain and adding value to this product (BEHLING et al., 2009), benefiting local producers harmed by the large-scale production systems.

However, these proposals require a wider approach than just the carbon footprint, and must include concerns related to consumers' acceptation, rural development and a host of others issues (PRETTY et al., 2005; COLEY; HOWARD; WINTER, 2009). Furthermore, the establishment of a short or local food supply chain is a hard task and faces many uncertainties. Therefore, this research aims to verify the municipalities where it might be interesting to invest in a local beef production in the State of Rio Grande do Sul, southern Brazil.

\subsection{BACKGROUND}

At the beginning, local food was consumed by producers, that traded, exchanged or gave away any surplus of its production to the local community (LYON; COLQUHOUN; JANHONEN-ABRUQUAH, 2003). Nowadays, a new discussion rises in Europe highlighting concepts of local and short supply chains as alternative food systems (DELIND, 2011). The scholars that defend these initiatives claim it has a smaller carbon footprint related to transport, are more climate-friendly, and minimize the greenhouse gas emissions (MARKUSZEWSKA et al., 2012), the latter, a concern in beef production.

The alternative food chains are the face to face interaction as seen in direct sales at the farms; spatial proximity by offering to local consumers information regarding local food production through labels and marketing, and/or the development of value associating differentiated places and process to the final product (MARSDEN; 
BANKS; BRISTOW, 2000; PEARSON; BAILEY, 2009; PEARSON et al., 2011). These authors characterized short food supply chains not only by lessening the times food is handled or by the distance it travels, but also by embedding information to the product via signalizations. Moreover, the shorter the supply chain, the easier it is to maintain and communicate those product differentiations, such as cultural identity or traditional products (MARKUSZEWSKA et al., 2012).

Nevertheless, there is a lack of legislation and even of a widely accepted definition of local food (JONES; COMFORT; HILLIER, 2004; FEAGAN, 2007). The most commonly approach defines it according to the distance food travels from production to consumption (PEARSON et al., 2011). Within this precept, different local networks were proposed around the world. In Edinburgh, the farmers' market operates within a 100 miles $(160 \mathrm{~km})$ radius, and the United Kingdom's National Farmers' Retail \& Markets Association states it should be no more than a 30 miles radius to maintain local proprieties (LYON; COLQUHOUN; JANHONEN-ABRUQUAH, 2003).

Although a legal framework is yet to be established, investing in local food is a way to reconnect local producers and regional consumers (WINTER, 2005). Furthermore, since food is a result of natural resources and the heterogeneity of the production conditions, waging in those strategies contributes to increase food diversity. Nevertheless, establishing an alternative food network requires a production adapted to its environment, and according to consumers' expectations of quality and safety of the food (COLEY; HOWARD; WINTER, 2009).

The promotion of those products is seen at many supermarkets, one of whom offers 2,500 products from 600 local suppliers in Europe, which are produced within 30 miles, (WAITROSE, 2013). Tesco supermarket had also taking advantage of local food, offering many products with that differentiation, but considering a much larger region in England as local. Their requirements for carbon footprint labels incited others supermarkets to replace international food suppliers in the name of sustainability (MORGAN, 2010), such as avoiding food imported from overseas and buying local. Notwithstanding, others scholars highlighted their worries regarding the use of those concepts, afraid they are being used as polemical tools to harm food production in the developing countries (COLEY; HOWARD; WINTER, 2009). 


\subsection{BEEF DIFFERENTIALS OFFERED BY RIO GRANDE DO SUL, SOUTHERN BRAZIL}

Rio Grande do Sul presents a different scenario from the rest of the country. The milder weather, the traditions of its population and the beef production of this State reflects its proximity to Argentina and Uruguay. Notwithstanding, the market opening had a major impact in its beef production, aggravated by the establishment of MERCOSUL, after which many producers couldn't respond to the competition against their neighbor countries (Argentina and Uruguay), and the new Brazilian production centers, such as the Midwest region.

However, this State has many advantages regarding quality associated do beef. Among its advantages are high genetic availability, natural pasture (CARVALHO; BATELLO, 2009), favorable climate and soil conditions (NABINGER et al., 2009; BARCELLOS et al., 2011), slaughterhouses habilitated to export (OLIVEIRA et al., 2014), beef farmers associations, scientific support provide by federal institutions as EMBRAPA - "Empresa Brasileira de Pesquisa Agropecuária"; universities, and, maybe the most important, the culture and tradition of the gaucho ${ }^{3}$ way of life (Faria, 2000; Boldrini et al., 2010). Furthermore, in 2006 the municipalities of Aceguá, Bagé, Candiota, Dom Pedrito, Hulha Negra, Lavras do Sul, Pedras Altas and Pinheiro Machado received an geographical indication for beef "Carne do Pampa Gaúcho da Campanha Meridional” (INPI, 2013).

The geographical indication represents an asset originated within a countries' territory or a region, where a given quality, reputation or other characteristic are attributable to its geographical origin (BARHAM, 2003). Although other research found a possibility for a geographical clusters in beef producers from Rio Grande do Sul, they lack coordination and integration to sustain that competitive benefits (MALAFAIA; BARCELLOS, 2007). Moreover, these producers have a problem regarding trust and cooperation among each other's.

The pasture-fed beef is leaner, presents higher levels of omega-3 fatty acid, and of conjugated linoleic acid (CLA). While the first help to reduce the risk of coronary heart disease, the CLA is said to have anticarcinogenic properties (Pavan and Duckett, 2013). Moreover, European consumers for Uruguayan beef had higher acceptance for beef produced only in pastures with low supplementation levels (

3 Meaning original from the Rio Grande do Sul State. 
REALINI et al., 2013), which is produced in similar conditions as in Rio Grande do Sul.

Furthermore, the southern fields in RS are different from the rest of the Brazilian pastures. For starters it wasn't a forest that was transformed in pasture, it was originally a vast extension of fields (SUERTEGARAY; SILVA, 2009). In addition, those fields are in threat of being replaced by forests (natural and anthropogenic) and the production of ruminants, without overcrowding the pastures, is the conservation strategy indicated to maintain this Biome and its unique biodiversity (CASTILHOS; MACHADO; PINTO, 2009).

\section{METHODS}

Since we are proposing a local production approach, and believing in a different beef offered by the State of Rio Grande do Sul (Figure 1) we identified the cattle units slaughtered and the estimated beef consumption of each municipality to evaluate whether and where a local beef supply chain might be interesting.
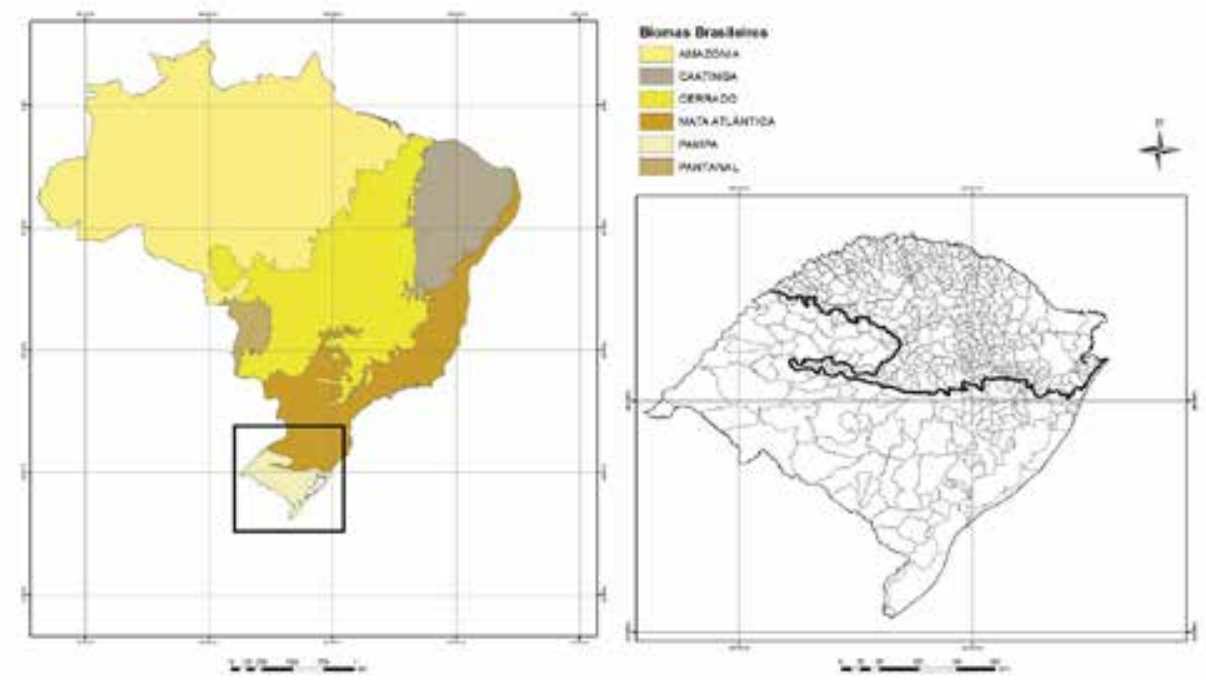

Fig. 1. Geographical location of the Brazilian biomes. The State of Rio Grande do Sul is indicated by the square and in highlight, indicating the political boundaries of the municipalities of this region and its effective cattle. 
The average beef consumption in Rio Grande do Sul was established (GENRO et al., 2012), and then multiplied by the resident population to estimate the beef consumption in each municipality. The cattle units slaughtered was selected at the Ministry of Agriculture, Livestock and Food Supply website (SIF, 2013), and a sum of all the categories was used ( 14.023 .367 cattle units). These indicators were applied to identify the capacity of the municipality to meet its own demand for beef, and therefore, to enable the development of a local beef production.

The indicator was determined by dividing the total of beef from the municipalities ${ }^{4}$, by their estimated beef consumption. Results close to one represent a location where the actual production may meet their own demand for beef; regions with a capacity much higher than one indicate location where the surplus enables a mixed food production capable of attending local demand for beef and taking advantage of exportation. Municipalities with values close to zero are unable to meet its beef demand.

The location of the slaughterhouses was identified to verify the availability of processing beef industries within the municipality or inside the 30 miles (48 kilometers) radius, as proposed by the European Union (Markuszewska et al., 2012). To evaluate whether the areas with high capacity might also benefit small farmers, the number of establishments with less than 200 hectares, dedicated to livestock and other animals production in each of the municipalities was identified (IBGE, 2006).

All data was associated to the map of Rio Grande do Sul State, according to the 2008 political division of municipalities (FEE, 2007) by the Quantum GIS 1.8 Lisboa software. The geodetic system applied was the South American Datum (SAD69) usually used for analysis in South America. The categorizations of the municipalities were evaluated by Jenks natural breaks classification method (applied in the figures 1 and 3), except for the municipalities capacity to meet their own demand indicator, which was categorized to better identify the municipalities with capacity close to one.

4 According to the common minimum carcass yield of 220 kilograms per cattle unit slaughtered (Pascoal et al., 2010). 


\section{RESULTS}

The municipalities were graded according to the cattle units slaughtered original from its territory (Fig. 2), and the most prominent regions were located at the southwest, in the Campanba Region, within the limits of the Pampa Biome, and some at the northeast, near the mountain region, in the Atlantic Rain Forest. The municipalities that provided a high number of cattle to the State and had a slaughterhouse with federal inspection inside their territory were Alegrete and Bagé.

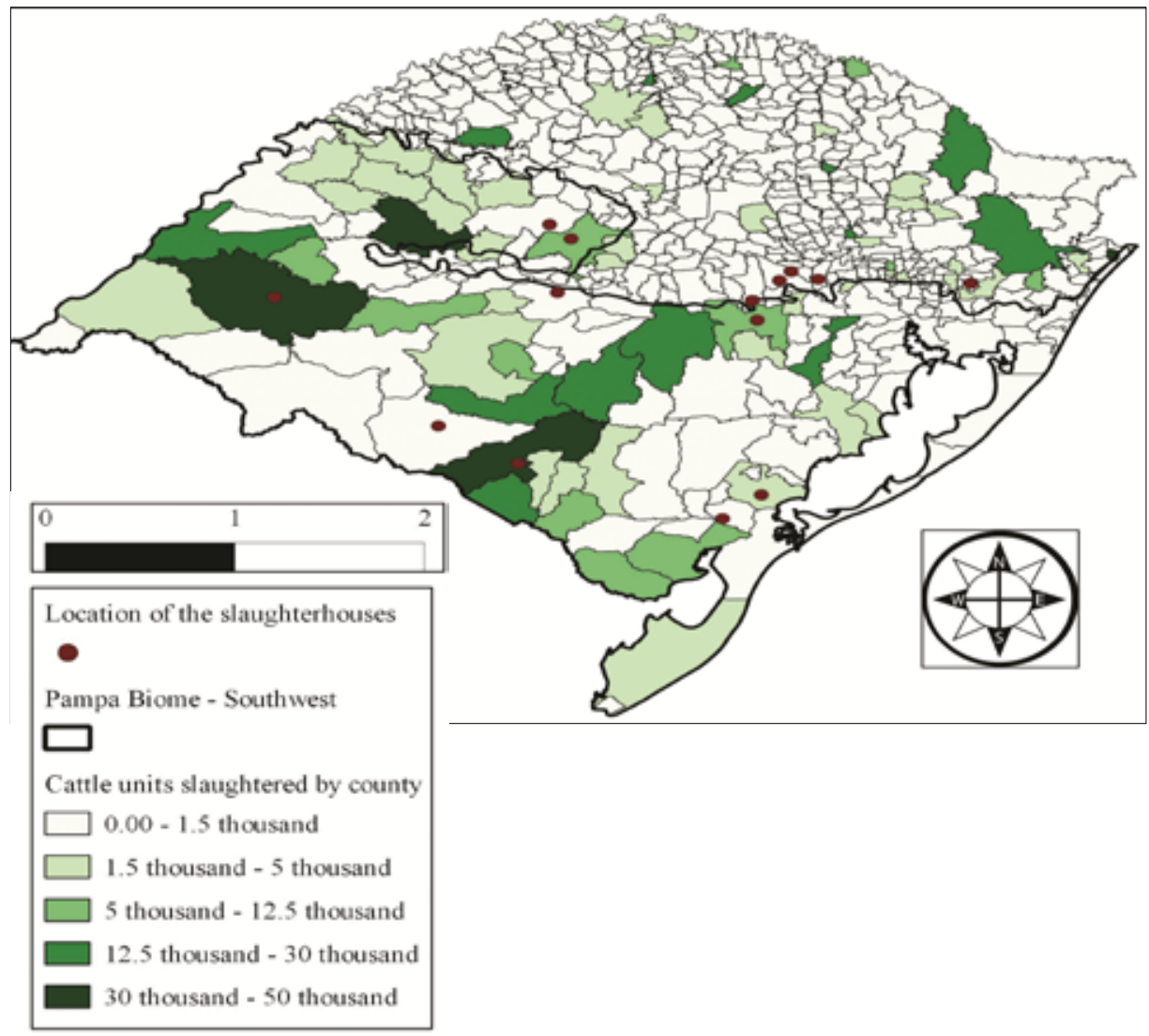

Fig. 2. Cattle units slaughtered from each municipality of Rio Grande do Sul State, Southern Brazil, in the year of 2012.

Source: Elaborated by the author according to the Brazilian Federal Inspection Services (SIF, 2013). 
When the number of cattle units slaughtered from each municipality was related to the estimated beef consumption the municipalities of Aceguá, Pedras Altas, Machadinho, São Valentim, Quatro irmãos and Sagrada Família (scattered along the northeast) as location of very high cattle unit slaughtered, surpassing the municipality capacity to absorb this production (Fig. 3).

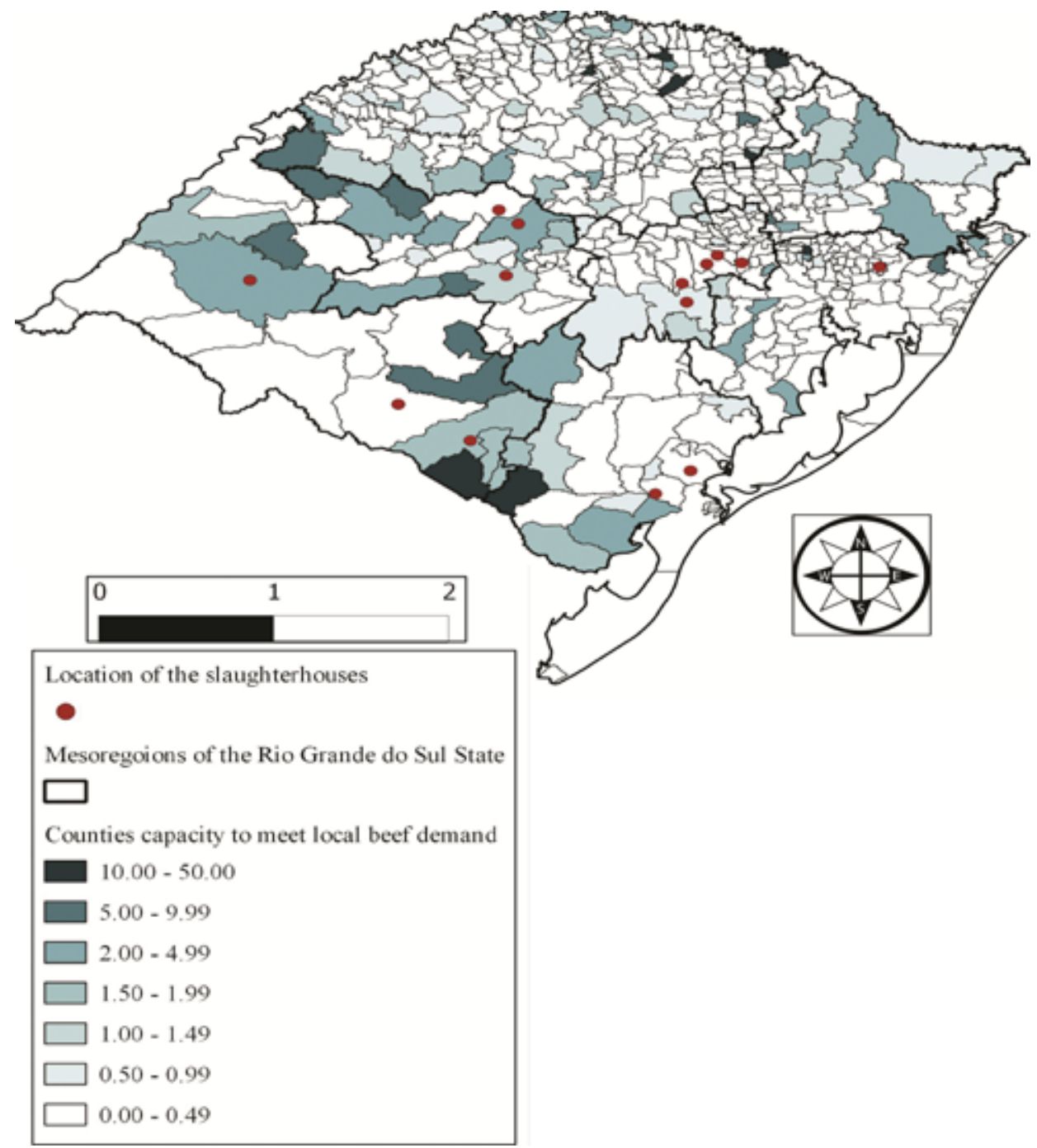

Fig. 3. Estimated capacity of the municipalities' beef production to meet their own demand for beef products in Rio Grande do Sul State, Southern Brazil. Source: Elaborated by the authors. 
The areas with higher number of small beef producers' are concentrated at the southwest and south regions, and some are within the 30 miles radius from the slaughterhouse, as in Alegrete. In this municipality, a local beef production, based on the 30 miles distance or on the municipality's limits, will benefit more small producers, but it would also be interesting in Dom Pedrito. Other municipalities are also in a radius around the slaughterhouses capable of attending many local producers such as Bagé, Santa Maria, Júlio de Castilhos, and Pelotas (Fig. 4).

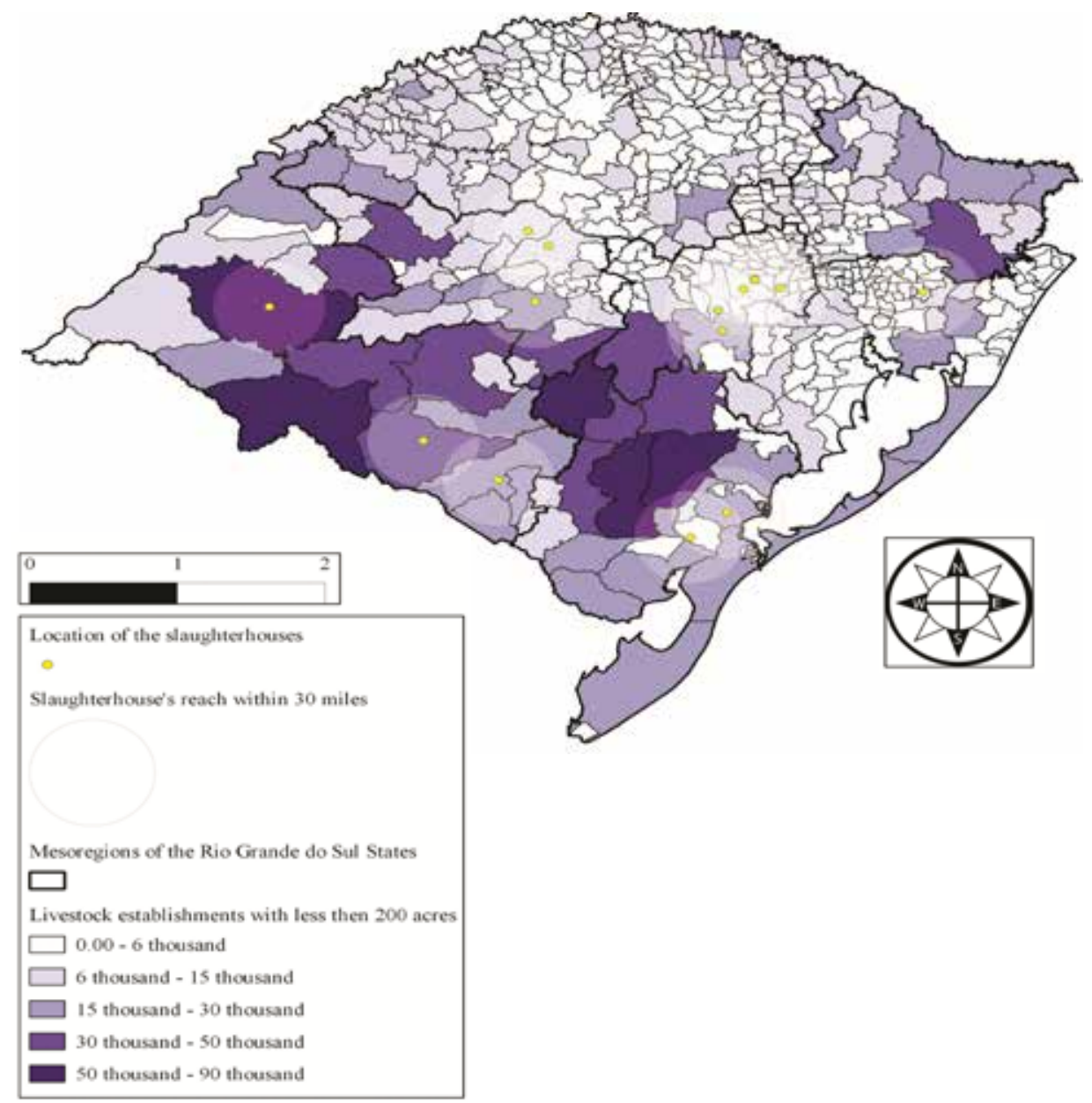

Fig. 4. Number of establishment dedicated to livestock and other animal production in the Rio Grande do Sul State, southern Brazil in 2006. The transparent white circles represent the area within 30 miles from the slaughterhouses. Source: Elaborated by the author according to data available at Brazilian Institute of geographical and Statistics web site (IBGE, 2006). 


\section{DISCUSSION}

The mesoregions most prominent for beef production are places where other agriculture find it hard to evolve. Therefore, some municipalities face fertility difficulties and low profit in beef production. Nevertheless, those municipalities carry hundreds of years of a traditional production and cultural aspects of the Gaúcho way of life.

The fact that there is a strong culture in the state and an established beef production, allowed the creation of a geographical indication certification, enabling a differentiated product with aggregated value. This kind of strategy can shorten the supply chain, and since the product identity is established, it provides a connection with the consumers.

The strategic actions developed by the Carne do Pampa Gaúcho da Campanba Meridional had focused so far in attending the international expectations, specially of the European Union, searching for better remuneration, without dedicating itself to conquer the appreciation of the Brazilian consumers. On the other hand, the European strategy is to invest in their own producers, sometimes associating the concepts of local food production, and other times by stating that food travelling overseas is harmful to the environment when the carbon footprint is considered (MARKUSZEWSKA et al., 2012).

Apart from the protectionisms, many beef farmers are taking advantage of those projects. In Italy, a farmers' cooperative offers organic beef sausages based on quality and tradition, raising their prices by $30 \%$. The quality brand also stimulated the ownership sense and improved cooperation among producers and between farmers and other local actors (MARKUSZEWSKA et al., 2012), and Gaúcho beef production is in need of all those attributes.

In beef production, a direct sale that ensures quality and safety might be compromised by the necessity of proper inspection, which is difficult inside a farm. Nevertheless, a direct sale maybe achieve at the slaughterhouse, eliminating the retail and approximating consumers to the first stages of food production and increasing the appropriation of the final product's value, without increasing the price for the final consumer. Moreover, it would attend the precepts for food safety, although 
demanding constant and capacitated human resources, which usually favors the large-scale industries (PEARSON et al., 2011).

A local beef production might be interesting in municipalities with a slaughterhouse within their territory, as Alegrete and Bagé, both long timers in beef production. Although the Campanba region, where Bagé is located, had a geographical indication since 2006, there is a lack of research able to testify those differentials, and to present and ensure consumers of its benefits. These difficulties to coordinate and cooperate in the supply chain, and to promote those desirable features, compromise the capacity of this supply chain to take this opportunity, and earn the consumers' trust and premium prices.

Gaúcho beef production is also missing the opportunity to take advantage of its tourism potential. Beef festivals may assist the reinforcement of the culinary identity of this traditional region, as other products in Rio Grande do Sul. These gastronomic events connect the festivals' food to its location (e.g. National Candy Celebration - Festa Nacional do Doce, Pelotas-RS), which attracts tourists (CERETTA, 2012), and their money. At September $20^{\text {th }}$ the State celebrates the Revolução Farroupilha, a regional revolution against the Brazilian government, resulting in an independency declaration of the State from the rest of the country. Nowadays, many Gaúcho Tradition Centers (Centros de Tradição Gaúcha - CTGs) in almost all municipalities and in other Brazilian States, celebrate for a week this event, and that would be an appealing date for a beef festival.

Even though there is a lack of official identification of the beef produced at the mountain region, northeast of the state, that region had been investing in tourism strategies, associated to the rural life and landscapes, which can also be a recreational selling opportunity (PEARSON et al., 2011), and a reinforcement of the local cultural identity (MARKUSZEWSKA et al., 2012).

A governmental research found the farmers dedicated to tourism in RS are usually small and medium firms, managed by family, and supplied by local inputs, but there is lack sustainable practices and the use of internet or specialized tourism agencies for marketing. The Brazilian rural tourists usually travel for leisure, once a year and accompanied, they use the internet to plan the trip and seem to be more interested in the Mountain region northeast of RS (MTUR, 2009). 
As for the know-how of Gaúcho's livestock production, there is a current project developed to preserve the traditional culture in the Pampa region, the National Inventory of Cultural References - Livestock, Bagé/RS (Inventário Nacional de Referências Culturais - Pecuária, Bagé/RS) and in this case it considered all the old municipality of Bagé, comprising the municipalities of Aceguá, Candiota, Pinheiro Machado, Hulba Negra, Dom Pedrito and Pedras Altas nowadays (KOSBY; SILVA, 2013).

Nevertheless, local food also faces many difficulties such as the dubiousness of its environmental benefits influenced by a life cycle analyses (EDWARDS-JONES et al., 2008), suggesting that its carbon footprint would be higher since they do not benefit from the large-scale economies of mass production and transportation (PEARSON et al., 2011). Even though, is inadvisable to expect consumers to consider the life cycle analysis of every product they purchase, nor even that the institutions involved are capable of providing those information for every product (COLEY; HOWARD; WINTER, 2009).

Entering a local food strategy requires entrepreneurial farmers, as well as many other skill, involving trust and coopetition among them. Moreover, the initial cost of investment to create and promote those strategies and the logistics to ensure its operation require an innovative spirit, feature uncommon to small farmers (MARKUSZEWSKA et al., 2012).

Concepts such as sustainability and local foods are difficult to precisely define, enabling a never-ending debate regarding: what is local? Are its benefits real? Even in the United Kingdom, a research found most of the consumers expecting local foods to be original from their municipality or within 30 miles of the buying place, and more concerning, many believed that the supermarkets were the expected buying place for local food (MORGAN, 2010). In Rio Grande do Sul, it is possible to find at the supermarkets specific brands for breeds, such as Angus and Hereford, differentiations that represent the efforts of each breeders' association. Notwithstanding, there is a lack of products taking advantage of the conquered indication of source label.

Regarding the environment, local food stands for a simplification of the understanding that the further food travels to consumers' plate, the greater its 
negative environmental impact (KEMP et al., 2010). Moreover, aspects related to an ethical foodscape ${ }^{5}$ are related to positive contribution to human health, as they increase the availability and diversity of foods (PEARSON et al., 2011); and benefits small producers; animal welfare, and biodiversity (MORGAN, 2010), since local food producers are twice as likely to use traditional breeds and species, supporting cultural tradition. Food production diversity may also contribute to its resistance and ability to adapt to climatic changes (MARKUSZEWSKA et al., 2012) and abrupt price variations in the international market.

Moreover, it is a complication to expect of a subject to take responsibility for social problems, such as sustainable development or the maintenance of small local producers (ROFF, 2007). Therefore, consumers must be convinced that their behavior is important and has a true effect on the environment or social wellbeing represented in the product their buying (ROBERTS, 1996), which can be achieved through continuum informational campaigns and labeling programs (NURSE; ONOZAKA; THILMANY, 2010) based on scientific and trustful sources. The locavore ${ }^{6}$ in Europe has at his/her disposal electronic maps and databases to inform where to find recommended local food and how to enhance communication and connection with producers (DELIND, 2011). This is a simple solution to approximate producers and consumers in Rio Grande do Sul.

To develop a purchasing impulse from consumers to buy local, they need to be provided with that kind of information to perceive the differential benefits of that product, and to trust them. Moreover, the agents involved should be motivated and capacitated through knowledge, confidence, and skills to reinforce their brand (MARKUSZEWSKA et al., 2012), even more if we consider tourism strategies. Quality is a major issue in this discussion, since the motivations to buy local are usually emotional (DEFRA, 2008), and the main reason, at least for European consumers, are the high standards of freshness and taste, authenticity and known source, supporting local community, and environmental benefits expected from it (PEARSON et al., 2011).

5 The term foodscapes is related to the culinary culture of a place as defined by the interactions of a variety of factors such as geography, climate; religion, language, culture, practices and processes, history, social organization, ethnicity, science and technology.

6 Consumers who prefers to eat within his/her region. 
Beef consumers' acceptance and their willingness to pay for differentials were associated to labels in the United States (UMBERGER; MCFADDEN; SMITH, 2009), and many preferred grass-fed beef products, and were willing to pay a premium price for it, a preference associated to the superior nutritional content of that product in north America (EVANS et al., 2011). Gaúcho consumers seem to value certifications and traceability (VELHO et al., 2009; BARCELLOS et al., 2012), and associates geographical indication to quality, safety and trust, willing to pay a premium price for that product (BRANDÃO et al., 2012).

Another core issue is the fact that to be willing to pay a premium price for any product, favoring ethical aspects, requires a consumer with other problems of his life solved. In this context, a human being is only capable of considering a certain quantity of worries in his life, and you can't expect from them to invest in local beef, when they are considering to eat more chicken for economic reason, or more fish to favor their health (WEBER, 2006). On the other hand, beef is a special food usually select for celebrations and family reunions, especially in Rio Grande do Sul.

Gaúcho population also tends to be proud of its State, aspect perceived in many aspects of its routine. Opposed to other Brazilian states, the Gaúchos know the States' anthem by heart and celebrated the day they try to emancipate from the rest of the country. A Brazilian beer brand has taken advantage of its regionalism by stating their product was only available within the frontiers of Rio Grande do Sul. The Polar Export is a beer produced in the municipality of Estrela, and their marketing is based on the slogan - The best is from here (A melbor é daqui) (AMBEV, 2013).

\section{CONCLUSION}

Despite the uncertainties, local food offers many benefits, such as sustainability, high-quality and fresh food, community engagement, reconnection between rural and urban areas, regional development and lower transitional costs, consumers' awareness, knowledge and trust. Those benefits tend to remain in the local economy, achieving the economic multiplier effect, adding employment and 
development to the region (PEARSON et al., 2011).

As other before us (SONNINO; MARSDEN, 2006; MORGAN, 2010; DELIND, 2011), we believe in an integrated nonrestrictive development of local food production, since neither alternative nor conventional exporting food networks are able to solve the production dilemma in quantity, quality and ethical precepts on its own. Especially in those areas where we found an intense beef production, and therefore with an expressive surplus of production that is important for producers and for the local economy.

Regarding the sustainable aspect, the burden should not rest on the shoulders of one stakeholder of the supply chain, since none are able to solve such a complex issue by itself (SEYFANG, 2006). Thus, to place the responsibility only at the consumers it is dangerous and inefficient. However, the beef supply chain may take financial advantages from sustainable process even if this is not a solution for all stakeholders. Moreover, communication and cooperation are key to establish and maintain any local food project as a reconnection dream between consumers and nearest food producers.

Finally, there is potential for Rio Grande do Sul to develop a short beef supply chain. Despite the need of inspection, some regions can invest in an approximation between farmers and consumers, contribution to a short supply chain. This process can enable a differentiated and value-added product, allowing small producers to generate income, employment and protect the environment.

\section{REFERENCES}

AMBEV. Cerveja Polar. 2013. Available at: < http://www.polar.rs/ > Access in: Feb. 2016.

BARCELLOS, J.O.J. et al. Consumer perception of Brazilian traced beef. Revista Brasileira De Zootecnia-Brazilian Journal of Animal Science, v. 41, n. 3, p. 771774, Mar 2012.

BARCELLOS, J.O.J.; et al. Technological innovation and entrepreneurship in animal production. Revista Brasileira de Zootecnia, v. 40, n. Special Supplement, p. 189200, 2011. 
BEHLING, H. et al. Dinâmica dos campos no sul do Brasil durante o Quaternário Tardio. In: PILLAR, V.D.P.; MÜLLER, S.C. et al. (Ed.). Campos Sulinos: conservação e uso sustentável da biodiversidade. Brasília: Ministério do Meio Ambiente, 2009. $403 \mathrm{p}$.

BOLDRINI, I.I. A flora dos campos do Rio Grande do Sul. In: In: PILLAR, V.D.P.; MÜLLER, S.C. et al. (Ed.). Campos Sulinos: conservação e uso sustentável da biodiversidade. Brasília: Ministério do Meio Ambiente, 2009. 403p.

BRANDÃO, F.S. et al. Trust and added value on meat with geographic indication. Arquivo Brasileiro De Medicina Veterinaria E Zootecnia, v. 64, n. 2, p. 458-464, Apr 2012.

CARVALHO, P.C.D.; BATELLO, C. Access to land, livestock production and ecosystem conservation in the Brazilian Campos biome: The natural grasslands dilemma. Livestock Science, Amsterdam, v. 120, n. 1-2, p. 158-162, Jan 2009.

CASTILHOS, Z.M.D.S.; MACHADO, M.D.; PINTO, M.F. Produção animal com conservação da flora campestre do bioma Pampa. In: In: PILLAR, V.D.P.; MÜLLER, S.C. et al. (Ed.). Campos Sulinos: conservação e uso sustentável da biodiversidade. Brasília: Ministério do Meio Ambiente, 2009. 403p.

CERETTA, C.C. Eventos de marca: evidências de valor turístico na gastronomia regional do Rio Grande do Sul/Brasil. Revista Rosa dos Ventos, v. 4, n. 1, p. 10, 2012.

COLEY, D.; HOWARD, M.; WINTER, M. Local food, food miles and carbon emissions: A comparison of farm shop and mass distribution approaches. Food Policy, v. 34, n. 2, p. 150-155, Apr 2009.

DEFRA. Understanding of consumer attitudes and actual purchasing behavior, with reference to local and regional foods. London: Department for Environment, Food and Rural Affairs, 2008.

DELIND, L.B. Are local food and the local food movement taking us where we want to go? Or are we hitching our wagons to the wrong stars? Agriculture and Human Values, v. 28, n. 2, p. 273-283, Jun 2011. 
EDWARDS-JONES, G. et al. Testing the assertion that 'local food is best': the challenges of an evidence-based approach. Trends in Food Science \& Technology, v. 19, n. 5, p. 265-274, 2008.

EVANS, J.R. et al. Determining Consumer Perceptions of and Willingness to Pay for Appalachian Grass-Fed Beef: An Experimental Economics Approach. Agricultural and Resoure Economicis Review, v. 40, n. 2, p. 18, 2011.

FARIA, S.C. Food in Brazil at the times of slavery. In: LAND and Food - 500 years of agriculture in Brazil. Brasília, DF: Ministério da Agricultura, pecuária e abastecimento, 2000. Cap. 2.

FEAGAN, R. The place of food: mapping out the 'local' in local food systems. Progress in Human Geography, v. 31, n. 1, p. 23-42, Feb 2007.

FEE - Fundação de Economia e Estatística Siegfried Emanuel Heuser. RS em mapas e dados: bases georreferenciadas para a comparação do desempenho socioeconômico dos municípios gaúchos entre 1966 e 2006. Porto Alegre, 2007.

GENRO, T. et al. Programa setorial Agroindústria Carne Bovina 2012-2014. Porto Alegre: Modelo de Desenvolvimento Industrial do Estado do Rio Grande do Sul. 55 p. 2012.

GODFRAY, H.C.J.E.A. Food Security: The Challenge of Feeding 9. Billion People: Science, v. 327: 812 p. 2010.

IBGE - Insituto Brasileiro de Geografia e Estatística. Censo Agropecuário 2006. Instituto Brasileiro de Geografia e Estatística - IBGE. Rio de Janeiro, p.1-777. 2006.

INPI - Instituto Nacional de Propriedade Industrial. Registros - Indicação Geográfica. Rio de Janeiro, 2013. Available at: < http://www.inpi.gov.br/menuservicos/indicacao-geografica/indicacao-geografica-no-brasil > . Access in: Feb. 2016.

JONES, P.; COMFORT, D.; HILLIER, D. A case study of local food and its route to market in the UK. British Food Journal, v. 106, n. 4, p. 328-35., 2004.

KEMP, K. et al. Food miles: Do UK consumers actually care? Food Policy, v. 35, n. 6, 
p. 504-513, Dec 2010 .

KOSBY, M.F.; SILVA, L.B.M.D. INRC - Lidas campeiras na região de Bagé/RS: inventário dos ofícios e modos de fazer da pecuária no Pampa. Revista Perspectivas Sociais, v. 2, n. 1, p. 12, 2013.

LYON, P.; COLQUHOUN, A.; JANHONEN-ABRUQUAH, H. Consumer confidence and UK food retailing: Why does local food matter? Journal of Food Agriculture \& Environment, v. 1, n. 1, p. 12-21, Jan 2003.

MANIATES, M.F. Individualization: Plant a Tree, Buy a Bike, Save the World? Global environmental politics, v. 1, n. 3, p. 21, 2001.

MARKUSZEWSKA, A. et al. Local Food and Short Supply Chains. European Commission. Belgium, p.1-72. 2012.

MARSDEN, T.; BANKS, J.; BRISTOW, G. Food supply chain approaches: Exploring their role in rural development. Sociologia Ruralis, v. 40, n. 4, p. 424-438, Oct 2000 .

MORGAN, K. Local and green, global and fair: the ethical foodscape and the politics of care. Environment and Planning A, v. 42, n. 8, p. 1852-1867, Aug 2010.

MTUR - Ministério do Turismo. Estudo de demanda para o turismo gaúcho. [s.l.]: Ministério do Turismo. 2009.

NABINGER, C. et al. Produção Animal com base no campo nativo: aplicação de resultados de pesquisa. In: PILLAR, V.P. et al. (Ed.). Campos Sulinos: conservação e uso sustentável da biodiversidade. Brasília: Ministério do Meio Ambiente, 2009. v.1, 403p.

NURSE, G.; ONOZAKA, Y.; THILMANY, D.D. Understanding the Connections between Consumer Motivations and Buying Behavior: The Case of the Local Food System Movement. Annual Meeting... 2010 Orlando, Florida: ASSOCIATION, S.A.E. , 2010. 19 p.

OLIVEIRA, T.E., BAUAZE, I.X.L.; FREITAS, D.S. Estrutura, conduta e desempenho 
como determinantes do preço do boi no estado do Rio Grande do Sul. Revista Agropecuária Gaúcha, v. 20, n. 1/2, p.137-145, 2014.

PASCOAL, L.L. et al. Beef cuts yield of steer carcasses graded according to conformation and weight. Brazilian Journal of Animal Science, v. 39, n. 6, p. 1363-1371, jun 2010.

PAVAN, E.; DUCKETT, S.K. Fatty acid composition and interrelationships among eight retail cuts of grass-feed beef. Meat Science, v. 93, n. 3, p. 371-377, Mar 2013.

PEARSON, D.; BAILEY, A. Sustainable Horticultural Supply Chains: the Case of Local Food Networks in the United Kingdom. In: INTERNATIONAL SYMPOSIUM ON HORTICULTURAL ECONOMICS AND MANAGEMENT, 16., v. 831, p. 131-137, 2009.

PEARSON, D. et al. Local food: understanding consumer motivations in innovative retail formats. British Food Journal, v. 113, n. 6-7, p. 886-899, 011.

POLLAN, M. The Omnivore's Dilemma: a natural history of four meals. New York: Penguin Group Inc., 2006. 450p.

PRETTY, J.N. et al. Farm costs and food miles: An assessment of the full cost of the UK weekly food basket. Food Policy, v. 30, n. 1, p. 1-19, Feb 2005.

REALINI, C.E. et al. Spanish, French and British consumers' acceptability of Uruguayan beef, and consumers' beef choice associated with country of origin, finishing diet and meat price. Meat Science, v. 95, n. 1, p. 14-21, Sep 2013.

ROBERTS, J.A. Green consumers in the 1990s: Profile and implications for advertising. Journal of Business Research, v. 36, n. 3, p. 217-231, jul 1996.

ROFF, R.J. Shopping for change? Neoliberalizing activism and the limits to eating non-GMO. Agriculture and Human Values, v. 24, n. 4, p. 511-522, dec 2007.

SEYFANG, G. Ecological citizenship and sustainable consumption: Examining local organic food networks. Journal of Rural Studies, v. 22, n. 4, p. 383-395, oct 2006.

SIF - Serviço de Inspeção Federal. Quantitativo de animais abatidos por categoria e unidade federativa. Available at: < http://www.agricultura.gov.br/portal/page/ 
portal/Internet-MAPA/pagina-inicial/servicos-e-sistemas/sistemas/sif $>$. Access in: Feb. 2016.

SONNINO, R.; MARSDEN, T. Beyond the divide: rethinking relationships between alternative and conventional food networks in Europe. Journal of Economic Geography, v. 6, n. 2, p. 181-199, apr 2006.

SUERTEGARAY, D.M.A.; SILVA, L.A.P.D. Tchê, Pampa: histórias da natureza gaúcha. In: PILLAR, V.D.P.;MÜLLER, S.C. et al (Ed.). Campos sulinos : conservação e uso sustentável da biodiversidade. Brasília: Ministério do Meio Ambiente, 2009. cap. 3, 403 p.

UMBERGER, W.J.; MCFADDEN, D D.T.; SMITH, A.R. Does Altruism Play a Role in Determining US Consumer Preferences and Willingness to Pay for Natural and Regionally Produced Beef? Agribusiness, v. 25, n. 2, p. 268-285, Spr 2009.

VELHO, J.P. et al. Willingness of consumers from Porto Alegre municipality, Rio Grande do Sul state, for purchasing beef meat with certification. Brazilian Journal of Animal Science, v. 38, n. 2, p. 399-404, Feb 2009.

WAITROSE. Regional and local sourcing. 2013. Available at: < http://www.waitrose. com/home/inspiration/about_waitrose/the_waitrose_way/the_origin_of_our_food. html >. Access in: Feb. 2016.

WEBER, E.U. Experience-based and description-based perceptions of long-term risk: why global warming does not scare us (yet). Climate Change, v. 77, p. 17, 2006.

WINTER, M. Geographies of food: agro-food geographies - food, nature, farmers and agency. Progress in Human Geography, v. 29, n. 5, p. 609-617, oct 2005.

Recebido em: 19 de setembro de 2014 Aceito em: 25 de julbo de 2016 